Михальська Л. В., керівник центру гематології та хіміотерапії гематостобластозів Клінічна лікарня "Феофанія» м. Київ, Україна

DOI: https://doi.org/10.30525/978-9934-26-064-3-23

\title{
СТРАТЕГІЧНИЙ МЕНЕДЖМЕНТ В ЗАКЛАДАХ ОХОРОНИ ЗДОРОВ'Я
}

Доцільно зазначити, що останнім часом Україна докладає багато зусиль для стабілізації ситуації в сфері охорони здоров'я, однак вона лишається досить складною.

Актуальність проблеми стратегічного управління вітчизняними медичними закладами обумовлена динамічністю життєвого циклу продукту медичних проектів на фоні жорсткого 
конкурентного оточення, необхідність якісного задоволення потреб у лікуванні пацієнтів.

Проблеми сфери охорони здоров'я мають значно ширший, багатоаспектний комплексний характер, серед яких ефективність управління організаційними змінами в закладах охорони здоров'я в Україні що й обумовило актуальність нашого дослідження. Ефективне стратегічне управління є однією з ключових позицій на шляху до удосконалення роботи закладів охорони здоров'я.

Перш за все, заклади охорони здоров'я - це певна соціальноекологічна система, що має особливі матеріальні, фінансові та трудові ресурси для задоволення потреб у медичних послугах. Сукупність можливостей лікувально-профілактичних закладів 3 надання послуг характеризує його потенціал в цілому. Можливості визначають наявні ресурси, що $є$ у розпорядженні лікувально-профілактичних закладів.

Функції та методи управління в охороні здоров'я підпорядковані основним законам світового менеджменту, але мають певні особливості.

В сучасних умовах ринкової економіки у процесі управління необхідно досягти не лише медичної та соціальної, а й економічної ефективності.

Розробка стратегії лікувально-профілактичних закладів - це науковий спосіб визначення стану закладу та ймовірних шляхів його розвитку за допомогою визначення системи бажаних якісних характеристик конкретного об’єкта управління в майбутньому. Основні методи отримання якісних характеристик при стратегічному плануванні представимо у вигляді рисунка 1.

Стратегія - це загальна концепція того, як досягати цілей організації, вирішувати різні проблеми та розподіляти необхідні для цього обмежені ресурси. За формою стратегія - це різновид управлінських документів, який може мати вигляд графіків, таблиць, описів тощо. За змістом - це модель дій, інструмент для досягнення цілей організації. Головним завданням розробки стратегії $є$ досягнення конкурентних переваг і рентабельності організації. 


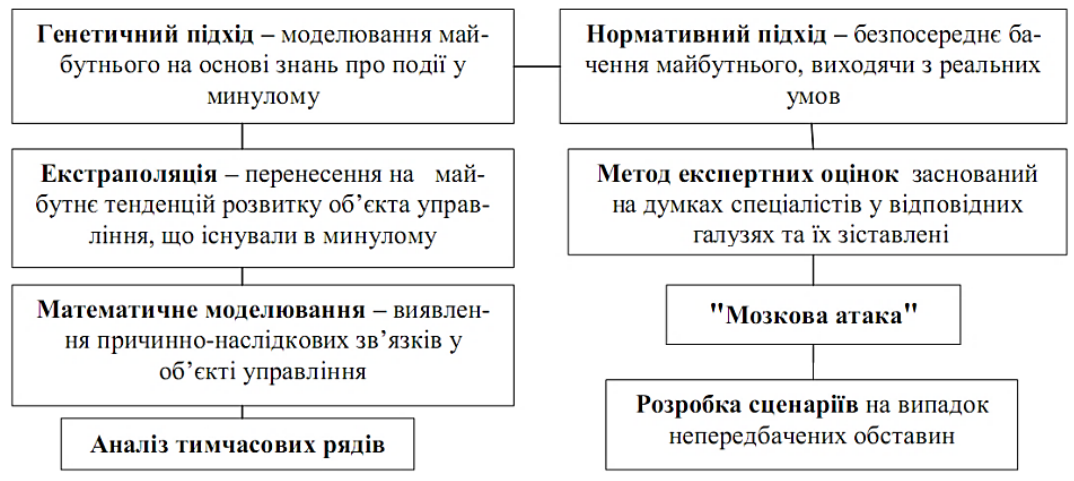

\section{Рис. 1. Методи отримання якісних характеристик об'скта стратегічного управління в майбутньому}

Джерело: [2, с. 38]

Стратегічне управління - це філософія та ідеологія менеджменту. Кожний менеджер реалізує ії по-своєму, залежно від багатьох чинників.

Стратегічне управління - це таке управління організацією, яке спирається на людський потенціал як основу організації, орієнтує виробничу діяльність на запит споживачів, гнучко реагує i проводить своєчасні зміни в організації, що відповідають виклику з боку оточення і дозволяють домагатися конкурентних переваг, що в сукупності дає організації можливість виживати в довгостроковій перспективі, досягаючи при цьому своїх цілей $[1$, c. 19$]$.

Реалізацію стратегії лікувально-профілактичних закладів спрямовано на виконування трьох взаємозв'язаних завдань:

1) визначення пріоритетності завдань, відносна значимість яких відповідала б тій стратегії, яку буде реалізовувати організація. Це стосується проблем використання ресурсів, формування організаційних відносин, створення допоміжних систем і т. ін.

2) встановлення відповідності між обраною стратегією та внутрішньо організаційними процесами в лікувально-профілактичних закладів для того, щоб зорієнтувати діяльність 
організації на здійснення стратегії. Відповідність встановлюють за такими характеристиками: - структура організації; - система мотивації та стимулювання; - норми та правила поведінки; кваліфікація працівників і менеджерів тощо.

3) вибір відповідного до здійснюваної стратегії стилю лідерства та підходу до управління організацією. На практиці існує три основні види стратегічного управління (рис. 2) [2, с. 40 ].

\section{Види стратегічного управління}

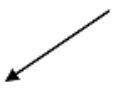

Випереджуюче

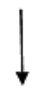

Застосовують за умови повного визначення та завбачення майбутнього організації. Реалізувати можна лише обмеженим набором функцій, пов'язаних 3

технологічними процесами виробництва та надання послуг

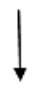

На основі передбачення змін

Виходить не із здійснених тенденцій $\mathrm{i}$ умов, а 3 тих, що можуть скластися в майбутньому і чиї ознаки в даний момент відсутні. Мета прогноз майбутньої ситуації та забезпечення на цій основі виживання закладу у перспективі.

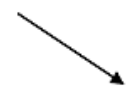

На основі вирішення стратегічних завдань

Не має своєю метою принципові зміни "обличчя" організації та забезпечення іï стратегічної здатності до виживання, а орієнтований на тактичну здатність до виживання, в основі якої лежить збереження позицій закладу в основних сферах його діяльності

\section{Рис. 2. Основні види стратегічного управління}

Для здійснення стратегічного управління необхідно володіти методами управління. Більшість методів управління спрямовано на мінімізацію стану невизначеності у процесі функціонування організації. Це сприяє стратегічному плануванню, у рамках якого застосовують сукупність методів стратегічного управління.

Стратегічні плани можуть бути генеральними, функціональними, економічними. Успішне виконання стратегічного плану передбачає застосування не тільки загальних, а й 
приватних методів управління, якими $\epsilon$ : видання наказів, планових завдань; проведення оперативних нарад, зборів; організаційне регламентування та нормування; економічне стимулювання тощо.

Необхідність якісного задоволення потреб у лікуванні клієнтів, застарілість існуючої системи охорони здоров'я, часто формальність та неефективність існуючого стратегічного планування в закладах охорони здоров'я, необхідність створення ефективної системи охорони здоров'я, що відповідає стандартам Європейського союзу, впровадження сучасних методів управління - вказують на потребу грунтовного вивчення та системного аналізу саме в площині проектно-орієнтованого підходу.

Стратегічне управління дозволяє досягти високої ефективності функціональної діяльності об'єктів охорони здоров'я за умови здійснення постійного контролю кожного кроку 3 метою підтримки належної якісті медичних послуг, застосування всіх доступних економічних методів управління. Разом 3 тим, стратегічне управління медичними закладми забезпечує економічну, соціальну та наукову перевагу на конкретному ринку медичних послуг.

\section{Література:}

1. Менеджмент : учебник / О.С. Виханский, А.И. Наумов. 5-е изд. стереотипн. Москва : Магистр : ИНФРА-М, 2014. 576 с.

2. Основи менеджменту i маркетингу в медицині: навч. посіб. / Т.В. Єрошкіна, О.П. Татаровський, Т.М. Полішко, С.С. Борисенко. Дніпропетровськ : РВВ ДНУ, 2012. 64c.

3. Лехан В.М., Крячкова Л.В., Волчек В.В. Управління змінами в системі охорони здоров'я України: історія та уроки пілотних регіонів : навчальний посібник. Дніпропетровськ, 2016. 53 с. 